\title{
Formation Mechanism and Countermeasures on Classroom Phubber in Colleges and Universities of Liaoning Province
}

\author{
Shan $\mathrm{Hu}^{\mathrm{a}}$, Jun Yang \\ School of Education and Sports, Bohai University, Jinzhou, 121013, China \\ a349645000@qq.com, byj690213@126.com
}

\begin{abstract}
Keywords: colleges and universities; classroom; phubber; research framework; formation mechanism; countermeasures
\end{abstract}

\begin{abstract}
Study selection of Liaoning college classroom phubber as the theme, trying to examine the current situation in the classroom phubber universities of Liaoning province, based on the factors affecting the college classroom phubber formed within a certain range, to scale, open-ended questionnaires and interviews and other forms of aid investigation. And try to make colleges and universities classroom phubber countermeasures, which need to rely on the community, schools, teachers, parents and students themselves joint efforts to build a harmonious campus atmosphere by strengthening classroom management, innovative teaching methods, teaching mode change, strengthen psychological counseling and other ways to improve the colleges and universities classroom "phubber" phenomenon, lectures enable students to form good study habits, to provide an effective reference and guidance for colleges and universities classroom phubber research and practice.
\end{abstract}

\section{Introduction}

The 21st century, "mobile phone addiction" has become a social "epidemic", and this disease is widely popular on college campuses. Students often use the mobile phone network locations are: classrooms, dormitories, dining hall, library, school class of the road. Of these, 69.7 percent of students said their own Internet access in the classroom every day, there are $85.9 \%$ of the students that the use of the mobile phone network is very common in the classroom, creating a large number of colleges and universities class "phubber" [1-3]. phubber, by the Australian Macquarie Dictionary of Mackenzie and fiction come together well, to describe those who simply looked down at the phone and in front of friends and relatives left out. [4-5] On classroom teaching in Colleges and universities "phubber" can be understood as: do not listen to the teacher carefully, countersunk concentrate on mobile phone screen brush, concentrate on to use the tablet PC or notebook computer Internet, playing games, watching videos, glued to the screen as a way, to spend time in the classroom for the purpose of students. Classroom "phubber" is a common problem faced by many university classrooms, seriously affected the student's academic teaching effectiveness, teachers. Competition between teachers and phones, has become a worldwide education.

\section{Research Framework}

Study selection in Liaoning colleges and universities classroom phubber as the theme, tries to in the main mechanism of examine of Liaoning Province Colleges and universities classroom phubber status based analysis colleges and universities classroom phubber formation, try and puts forward the Countermeasures of colleges and universities classroom phubber. Research and practice of colleges and universities classroom phubber provide effective reference and guidance. The framework of the study shows that the overall thinking and research process of the study. Research framework shown in Fig. 1.

\section{Formation Mechanism on Classroom Phubber in Colleges and Universities}

Factors influencing the formation of colleges and universities in the classroom phubber, within a 
certain range, to scale, open-ended questionnaires and interviews and other forms of aid the investigation. Simply put, the causes colleges and universities phubber mainly in the following three aspects:

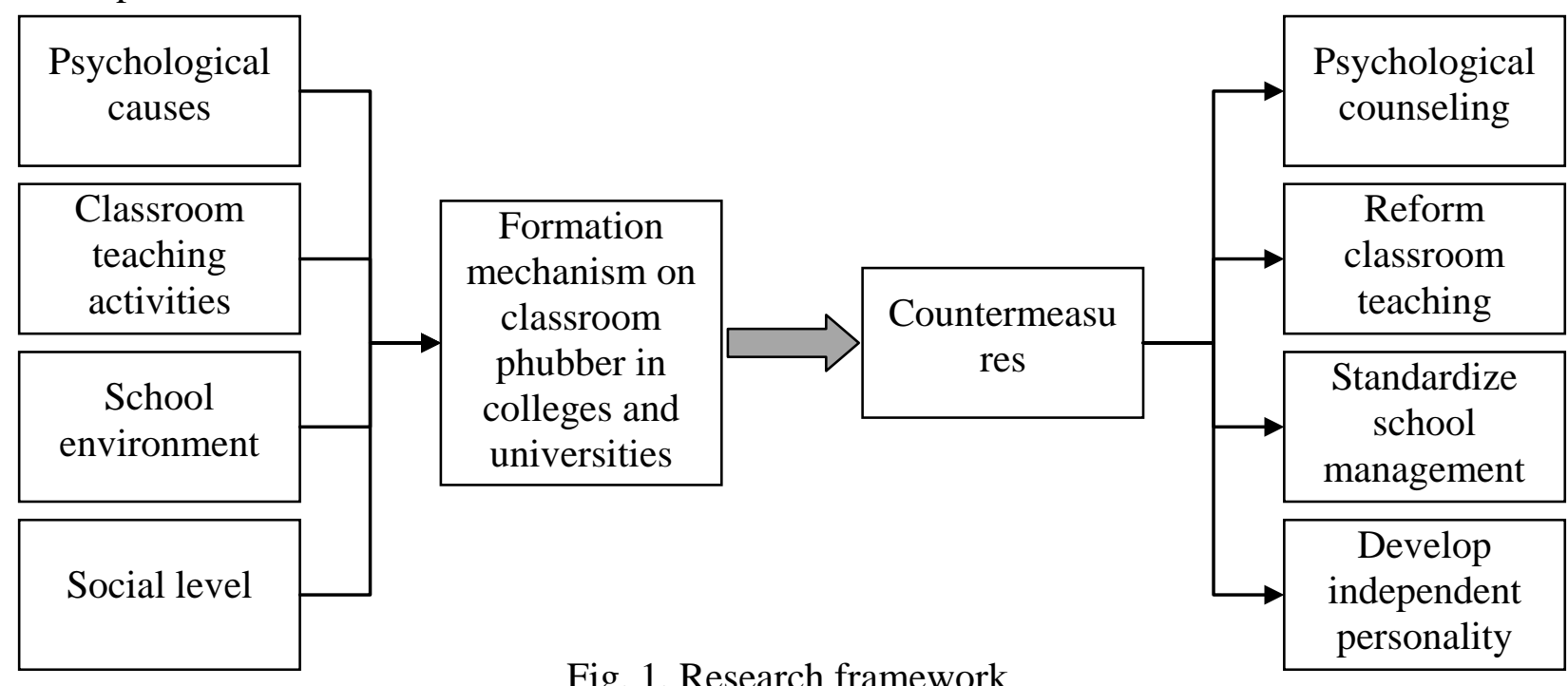

(1) Psychological Causes. According to group characteristics presentation Students phubber, mainly due to the security needs of its behavior, lack of ownership of needs and the needs of self-realization [6-8]. In terms of security requirements, college students thinking consciousness matures, already have their own ideas and ways of doing things. But in the face of indifference interpersonal and employment pressure and many other issues, is not easy to produce confident, lack of security and other negative impacts. The phone can play down the environment and all things around isolated, immersed in the virtual world, from an objective point of view, this is a means of self-protection and self-escape; Demand in the home, people want to get through with people love and care, and hope he can have good interpersonal skills. Many college students are searching information through social networks, build their own social network. phubber brush QQ micro letter every day, looking for chat topic, meet the demand for all kinds of information, and people can have an unlimited right to information; In the self-actualization needs, self-actualization needs Maslow's hierarchy of needs was identified as the highest level of life needs. And social networks, virtual games allow college students to easily achieve self-actualization needs, such as comments on the web, bask in the picture, look for the topic so almost without scruple to express their true thoughts, so their enthusiastic college students, college students for information makes them eager to continue to search for information through mobile media, they also want to engage the community self-realization.

(2) Classroom teaching behind. On the one hand, each of the current class rated colleges and universities because the more the number of teaching methods can still take the traditional lecture method, namely the teachers impart knowledge to students through oral language development of students' intellectual approach. But the mere thought of such teaching methods to mobilize the enthusiasm of students in class is far not. Teachers scripted lecture mode lack of passion, communication and exchange between students and fewer classes boring, boring teacher in the face when you explain, students find it very boring, "school teacher determines the quality of my phone traffic" , eventually leading to the entire class down, only to hear a teacher who speaks passionately on the podium, the podium silence, students would rather do "phubber" addicted to the virtual world of the mobile phone network; On the other hand, previous curriculum evaluation, the final volume scores accounted for the major proportion, classroom performance less proportion, students usually do not listen carefully in the class, assault exam review can also pass the exam. Students to participate in a small class, the initiation of the low head holding the phone to play their own ideas.

(3) School environmental factors. On the one hand, some colleges and universities teachers and students in order to facilitate access to information on campus to establish a wireless network, 
wireless network coverage so that students do not control the Internet, regardless of time and place of occasions, both in the restaurant, dormitory or classroom can be seen looking down a cell phone, chatting QQ, micro-blog, letter, brush with space, circle of friends, etc., especially in the classroom; On the other hand, the campus life is not rich is also one of the factors. School in single or in the form of monotonous life makes the students to be boring, and smart phones and the popularity of technological innovation, especially with the popularity of Mobile 3G and 4G networks, smart phone gradually become university life, darling, mobile phone for their provides sent the way, which can not only realize online at any time, at the same time, it can realize the function of entertainment. Thus, behind the rise of mobile phone overuse, it is highly dependent on people for the Internet. It called "addiction fingertips".

(4) Social dimension. Herd comparisons rampant. [9-10] Many college students "phubber" dependence on mobile phones, making it in the classroom is still reluctant to temporarily put it, I would rather do "phubber". The phone into the classroom will distract the attention of the students, the teacher will make the students can not keep up with the idea of not even normal interaction with the teacher, so that the classroom atmosphere becomes depressed, weakening the classroom as a learning place function. While using a mobile phone will be dispersed around the classroom the students' attention, many bow phenomenon, leading to lack of classroom learning environment, some students see their next table at the same table or using a mobile phone to play games or watch videos in the classroom when he (her) heart will itch, after hesitation struggle will become "phubber", unable to concentrate on lectures, because the herd mentality produces more "phubber". After 90 college students' consumption range is more and more wide, that is to say to be able to improve the level of consumption, so that the consumer has become a way to reflect the differences or levels of social groups. As a trendy mobile phone communication tool, it has become a fashion trend, college students show personality, highlighting the self-expression of an radical of a tool, especially in today's college students more emphasis on brand mobile phones, comparisons of the wind too clear. "Other people have, I would have," "other people play, I want to play" mentality, resulting in some students in mind is not to buy a mobile phone to contact friends and relatives, but just follow the trend comparisons. In addition, after the phone has, skilled use of the mobile client as their bragging rights. This herd, psychological comparisons ultimately lead to many college students on mobile phone dependence, so that the classroom is still reluctant to temporarily put your mobile phone, preferring to do "phubber".

\section{Countermeasures on Classroom Phubber in Colleges and Universities}

On the basis of investigation and analysis, the use of action research approach to flipped classroom teaching mode reform and psychological counseling individual students as the main point, to strengthen school and standardize management, and actively explore suitable for the actual university, targeted, operational implementation of the system of education .

(1) Strengthen psychological counseling. More and more students to become "phubber" the most important reason is that itself, therefore, from "phubber" psychological problem is the most fundamental way. Teachers, parents should give students to do the right psychological counseling, to talk with students, listen to the voices of the students, "mobile phone overuse" of the formation is not one or two days, it is long-term accumulation of bad habits that will produce a psychological fear and Masquerade ideas, unwilling to communicate with others. Faced with this situation, the school can offer specialized psychological counseling room, with psychological treatment enlighten the students, "looked up" to get rid "phubber". For students who indulge in phones for specialized psychological counseling, adjust the mentality of the students, from the phone to avoid tension and anxiety psychology appears.

(2) Reform of classroom teaching. First, teachers need innovative teaching methods. Teachers need to be innovative teaching methods in the classroom through their own experience and teaching experience of teaching to emulate the results of others, not just to teach the main method, according to the teaching discipline to set goals and tasks to select the appropriate teaching methods. Teachers should constantly improve their teaching and teaching art, creative teaching, mobilize the 
enthusiasm of students, to stimulate students' divergent thinking, interact with students in the classroom, to explain the limited knowledge of more than text, and more with a picture , video or instance, to achieve better teaching results, increase student interest in learning; Second, the flipped classroom teaching mode use, flexibility, high participation, so that students involved, a lot of communication between students and teachers, to a certain extent, improve teaching effectiveness, improve classroom quality universities. Teachers can be improved by practice law, task-driven law students to develop the ability to analyze and solve problems, students and other independent exploration and cooperative spirit. Such classroom, students will be able to "lift the head", he threw himself into learning in the classroom, rather than head down brush to proceed; third is to strengthen the reform of the examination system, improve classroom performance proportion. Reform of the examination system, according to the characteristics and content of the course, reform in the past, the final volume scores accounted for the major proportion in the test mode, improve the usual classroom performance in the examination subjects, accounts for the proportion, usually of classroom assessment, class to ask questions and so on, every time to give the corresponding scores, thereby reducing usually don't listen to the lecture, assault exam review can also through the examination of the phenomenon, to enable students to had to listen to the teacher carefully in class, keep up with the teacher thought, reduce the students use mobile phones.

(3) Standardized school management. First, universities should seriously classroom discipline, the development of relevant regulations, schools should establish a rational and strict management mechanism, to develop series of targeted measures to eliminate or reduce the student in the classroom use of mobile Internet behavior, such as shielding the signal, points, set the phone pouch, so that "phubber" classmate nowhere to hide. Schools should also develop and implement incentive mechanisms and enhance classroom quality-related, so that the vital interests of the quality of classroom instruction by hook; Second, rich campus culture. Now many universities most campus activities too old-fashioned, in the form of a single, lack of innovation, leading many students to campus life is very disappointed, opting instead for the Internet to play games or watching videos. Therefore, the school should actively building campus culture, carry out a variety of campus activities, to fully exploit the interest of students, conduct extensive variety in ideas, culture, entertainment, academic, scientific and technological content of the activities, such as competitions, various academic seminars, sports clubs, outdoor outing etc., to attract more students to participate, establish more realistic interpersonal communication, reducing the time "phubber" spent in the virtual world;

(4) Develop independent personality. Schools can organize students to participate in lectures related topics, warning students to "phubber" serious harm to bring their own, so that they understand that the herd is wrong, do not try to get rid of social reality through a virtual network, to a correct view of the surrounding friends, surrounding what happened thing. Through this ideological education, so that students gradually get rid of addicted to mobile phones, computers indulge psychological, a healthy independent personality. The maximum extent possible to meet the student diversified, multidimensional spiritual needs. Ideological and political education should give full attention to and meet the reasonable needs of inner growth and development of the students themselves, just enough so that students can truly understand and accept from the heart of our educational content and requirements.

\section{Conclusion}

"Phubber" The momentum is rising, timely curb is to solve the most fundamental way "phubber" prevalent in college classrooms. And this containment must rely on the community, schools, teachers, parents and students themselves several persons to work together to build a harmonious campus atmosphere by strengthening classroom management, innovative teaching methods, teaching mode change, strengthen psychological counseling and other ways to improve the College Classroom "phubber" phenomenon, so that students form good study habits lectures, achieve physical and mental development. 


\section{Acknowledgement}

This work is supported by 2016 annual economic and social development project in Liaoning province (2016lslktzixlx-01): Formation mechanism and countermeasure research the classroom' phubbing in colleges and universities in Liaoning; Education science planning project in Liaoning province (JG15ZXY04): Current situation investigation and countermeasure research on mental health education for college students in Liaoning province.

\section{References}

[1] X. Zhao, "Investigation and Analysis on the current situation of mobile phone network usage in College Students," E-Education Research, vol. 21, no. 4, pp. 43-47, 2014.

[2] Q. Zhang, "Research on the motivation and behavior of College Students' micro blog communication," E-Education Research, vol. 19, no. 8, pp. 55-58, 2012.

[3] G. K. Xu, C. P. Zhou, "Investigation and Analysis of University Students' Mobile Phone Reading Behaviors," Library and Information Service, vol. 56, no. 14, pp. 82-85,92 , 2012.

[4] Guan, S., Subrahmanyam, "Youth intemet use: Risks and opportunities," Current Opinion in Psychiatry Turkish Edition, 2009.

[5] Fioravanti, G., Dettore, D., \& Casale, S. "Adolescent Internet addiction: Testing the association between self-esteem, the perception of Internet attributes, and preference for online social interactions," Cyberpsychology, Behavior, And Social Networking, vol. 15, no. 16, pp. 318-323, 2012.

[6] Y. Z. Jiang, X. L. Bai, "The influence of mobile internet dependence of college students on Alienation: the role of social support system," Psychological Development and Education, vol. 30, no. 5, pp. 540-549, 2014.

[7] H. Liu, H. L. Wang, "The Relationship Among College Students Mobile Phone Addiction, Mobile Phone Use Motive and Loneliness," Journal of Psychological Science, vol. 34, no. 6, pp. 1453-1457, 2011.

[8] Y. Wang, "Cause analysis and solution of the phenomenon of college campus bow," Economic \& Trade, vol. 15, no. 8, pp. 235, 2015.

[9] Y. Peng, "Reasons and Countermeasures of the phenomenon of the phenomenon of the bow and bow in college class," Journal of Huainan Vocational \& Technical College, vol. 15, no. 4, pp. 41-44, 2015.

[10] H. L. Ding, H. Lan, L. L. Yu, "On the causes of the phenomenon of bow and bow in universities and Its Countermeasures," Theory Research, vol. 19, no. 17, pp. 53-54 , 2015. 